\title{
Lydia Wistisen
}

\section{Leken i antropocen \\ Skräpestetik i Barbro Lindgrens Loranga, Masarin och Dartanjang (1969) och Loranga, Loranga (1970)}

Play in the Anthropocene. Waste Aesthetics in Barbro Lindgren's Loranga, Masarin och Dartanjang (1969) and Loranga, Loranga (1970)

Abstract: The article examines the ecological and aesthetic dimensions of trash in Barbro Lindgren's children's books Loranga, Masarin och Dartanjang (1969) and Loranga, Loranga (1970). It investigates how Lindgren develops a waste aesthetics by inscribing the child, the play, and the children's book in a contemporary environmental critique of waste disposal. I argue that her aesthetics differs from the established image of political children's literature around 1968. The article contributes to the growing field of waste studies, a research area intertwined with material ecocriticism and modernity studies. Stories that connect waste with play and fantasy have the ability to work as counter-narratives and bridge the gulf between human culture and non-human nature. In a traditional environmental discourse nature is configured as a passive victim of exploitation and contamination. These kinds of narratives are performative in their disenchantment of the human-nature relationship, and perpetuate alienation and disinterest. Lindgren's waste aesthetics, on the other hand, encourages a productive relationship to trash and Loranga, Masarin och Dartanjang and Loranga, Loranga are examples of counter-narratives.

Keywords: Barbro Lindgren, waste studies, material ecocriticism, environmentalism, counter-narrative, 1968, playgrounds, toys, garbage, trash, dirt

(C)2018 Lydia Wistisen. This is an Open Access article distributed under the terms of the Creative Commons Attribution-Noncommercial 3.0 Unported License (http://creativecommons.org/ licenses/by-nc/3.0/), permitting all non-commercial use, distribution, and reproduction in any medium, provided the original work is properly cited.

Citation: Barnboken - tidskrift för barnlitteraturforskning/Journal of Children's Literature Research, Vol. 41, 2018 http://dx.doi.org/10.14811/clr.v41i0.316 
Bakom vedbon ligger en extrafin sophög och på sophögen ligger för det mesta en giraff och snarkar med huvudet i en gammal konservburk. (Lindgren, Loranga, Masarin och Dartanjang 7)

Loranga, Masarin och Dartanjang i Barbro Lindgrens Loranga, Masarin och Dartanjang (1969) och Loranga, Loranga (1970) bor i en by bestående av röda hus och omgiven av barrskog. Sedan tar likheterna med Bullerbyn och Lönneberga slut. Lorangas hem är en del av det moderna Sveriges landsbygd, med korvkiosker, anstalter och förfallna gårdar med sophögar bakom bruksbyggnader som inte längre används. Men det är också ett fantastiskt lekrum, där gränsen mellan fantasi och verklighet är upplöst, där det bor giraffer på sophögar.

I allmänna beskrivningar av barnlitteratur från perioden kring 1968 delas den mestadels in i två kategorier: den första beskrivs som socialrealistisk och politisk medan den andra relateras till konkret poesi, lekfullhet och fantasi (Kåreland, Barnboken 60 f.). Barnböcker som explicit behandlar miljöfrågor, såsom Annika Elmqvists Sprätten satt på toaletten (1970) eller danska Ib Spang Olsens Røgen (1970), placeras i den första, problemorienterade gruppen (Druker, "Från dystopier" 12). Loranga, Masarin och Dartanjang och Loranga, Loranga har däremot behäftats med ord som eskapistisk, rolig och gränsöverskridande (Mählqvist 132; Kåreland, Inga gåbortsföremål 124; Kriström 225). Stefan Mählqvist skriver till exempel att böckerna "gav upphov till befriande skratt i en tid då den svenska barn- och ungdomslitteraturen hade kritikens ögon på sig att skriva alltmer samhällsengagerade böcker" (132).

Lek och skratt behöver emellertid inte nödvändigtvis utesluta engagemang för miljön. Jag vill nyansera bilden av 1960- och 70-talens politiska barnbok genom att närma mig Loranga, Masarin och Dartanjang och Loranga, Loranga från ett den "extrafina" sophögens perspektiv. Det övergripande syftet är att undersöka hur Lindgrens skräpestetik skriver in barnet, leken och barnboken i en samtida miljödiskurs och aktualisering av vad som idag kallas antropocen, människans tidsålder. Jag menar att Lindgrens motiv, gestalter, miljöer och illustrationer är präglade av ett slags skräpets estetik som i sig är politisk. Trots att verken utgår från en tradition av absurd och rolig barnlitteratur ställer de flera frågor som under slutet av 1960-talet var högaktuella: frågor om urbanisering, resurshushållning, avfallshantering och kommersialism (Östberg 96 f.; Stahre 69; Boström). 


\section{Nedskräpning och skräpstudier}

En av de aspekter av 1968 års politiska nyorientering som haft störst inflytande på de efterföljande decenniernas politik är miljörörelsen. Under den period då Lindgren debuterade som författare bildades ett stort antal miljögrupper och organisationer i Sverige (Stahre 71 f.). I och med industrialisering, motorisering och nya konsumtionsvanor hade problem med avfallshantering, smuts och skräp ökat under 1950- och 60-talen. Glesbygdsproblematik, urbaniseringens och överflödssamhällets konsekvenser, föroreningar och miljögifter diskuterades därför på alla nivåer i samhället (Östberg 131). Flera rapporter om en accelererande miljöförstöring gavs ut och känslan av en kris i relationen mellan människa och miljö växte sig starkare (Haraldsson 21).

Den sophög som Lindgrens giraff ligger på stod med andra ord i centrum av den samtida debatten. 1962 lanserades den första större aktionen mot nedskräpning i Sverige på initiativ av Svenska Naturskyddsföreningen, kampanjen "Håll Naturen Ren". 1970 bildades sedan rikskommittén "Håll Sverige Rent". De producerade broschyrer, affischer, vykort och filmer, mycket av materialet var riktat mot barn (Rikskampanjen Håll Sverige rent 1970-1974 9). I häften som Gäst $i$ naturen (1963) citerades naturskyddslagen: "Envar skall tillse att han ej skräpar ned i naturen med glas, papper, avfall eller annat [...]" (8). I Land att vårda (1965) beskrevs den svenska naturen som "just nu utsatt för den snabbaste och mest genomgripande omvandling, som någonsin gått fram över landet efter istiden" (2).

I en nutida miljödiskurs används begreppet antropocen för att beskriva den omvandlingsperiod som följde på industrialiseringen av västvärlden och intensifierades efter andra världskriget. Begreppet har fått ett stort genomslag just för att det fokuserar frågor om människans åverkan på miljön, utsläpp och föroreningar. Det är omdebatterat, men enkelt förstått ett förslag på en geologisk epok där mänskligheten satt bestående avtryck på jordens klimat och ekologi (Morton). Den kollaps av gränsen mellan natur och kultur som antropocenbegreppet betecknar framträder tydligt i människans sophantering: det är föroreningar och avfall som lämnar spår $\mathrm{i}$ jordskorpan (Hawkins $10 \mathrm{f}$.).

I Lorangaböckerna är människans förändrade relation till naturen självklar. Nedskräpningen genomsyrar verken. För att undersöka Lindgrens skräpestetik kommer jag således använda mig av en linje inom de senaste decenniernas ekokritiska forskning kallad "waste studies", skräpstudier. Sedan tidigt 2000-tal har flera ekokritiska ar- 
beten publicerats som vänder blicken från natur till kultur, från vildmark och naturmiljöer till allt det avfall som följer på modernisering och urbanisering. Skräpstudier återfinns dels inom filosofisk, historisk, etnologisk forskning, dels inom det litteraturvetenskapliga fältet där forskare som Sophie Gee, Susan Signe Morrison och Rachele Dini propagerat för ett utökat undersökande av skräpets många skönlitterära funktioner. Även om inget särskilt fokus på det sena 1960-talets politiska utveckling finns i studierna är det framför allt skräpets gränsöverskridande egenskaper och politiska sprängkraft som framhävs. Till exempel menar både Gee i Making Waste. Leftovers and the Eighteenth-Century Imagination (2009) och Dini i Consumerism, Waste, and Re-Use in Twentieth-Century Fiction. Legacies of the Avant-Garde (2016) att förekomsten av skräp i skönlitteratur nästintill alltid är politiskt motiverad. Framför allt för att vad som räknas som avfall har med rådande samhällsförhållanden, sociala hierarkier och maktstrukturer att göra.

Resonemanget bygger på tanken om smuts som relativt, lanserad av Mary Douglas i Purity and Danger. An Analysis of Concepts of Pollution and Taboo (1966). Douglas placerar smuts i en etisk och politisk kontext genom att definiera det som "matter out of place", stoff som hamnat fel. Douglas menar att städning är ett sätt att återställa den moraliska ordningen (2). Smuts utgör aldrig en isolerad företeelse, där det finns smuts finns det alltid ett system. Smuts är en biprodukt av all typ av systematiskt ordnande och klassificerande av materia - i alla fall där ordna är lika med uteslutning av allt olämpligt (36). Det är ett exempel på vad Bruno Latour i Nous n'avons jamais été modernes. Essai d'anthropologie symétrique (1991) kallar "hybridkategori", en blandning av natur och kultur. Latour menar att den strävan efter renhet, ordning och skarpare avgränsningar mellan natur och kultur som Douglas beskriver, enbart kreerar fler blandformer och hybrider, mer smuts och skräp.

Latours tanke om hybridkategorier är grundläggande för den samtida ekokritikens förståelse av skräp. I The Ethics of Waste. How We Relate to Rubbish (2005) påpekar Gay Hawkins att ordet sopor inkluderar såväl organiskt som icke-organiskt material. Sopor beskrivs som en blandform vilken befinner sig i skärningspunkten mellan natur och kultur. Däri ligger också deras etiska och politiska potential. Miljönarrativ är performativa, de formar människors subjektiva förståelse av avfall och natur samt påverkar vardagen och relationen till den (Hawkins $10 \mathrm{f}$.). Inom en traditionell miljödiskurs är både människa och natur konfigurerade som förlorade. I berättelser om döende floder och berg av sopor framställs naturen som ett 
passivt offer för mänsklig exploatering och förorening, som att den bit för bit förlorar sin renhet och helighet. Människorna å sin sida framstår som alienerade från den naturliga världen, som att de mist kontakten med den fysiska miljön på vilken deras liv är avhängiga. Dylika skräpskildringar kan ge upphov till känslor av sorg och likgiltighet och därmed cementera precis den relation till naturen som de egentligen vill utmana: ett distanserat, ointresserat förhållande (Hawkins 8 f.).

Skildringar av smuts, skräp och avfall kan emellertid även ha en positiv effekt på människans relation till miljön. Om de framhäver skräpets hybridform och lyckas förändra förståelsen av förhållandet mellan natur och kultur kan de fungera som en katalysator för etiskt tänkande, insikter och medkänsla. Hawkins benämner sådana narrativ "motberättelser". En motberättelse kan bryta det negativa mönstret, återförtrolla naturen och överbygga dualismen mellan mänsklig kultur och ickemänsklig natur (Hawkins 10).

Inom skönlitteratur och konst finns flera exempel på motberättelser där skräp spelar en essentiell roll i form av brygga mellan natur och kultur. Morrison menar i The Literature of Waste. Material Ecopoetics and Ethical Matter (2015), att skönlitteratur och konst kan hjälpa människan att se skräp som etisk materia vilken uppmanar till handling. När ett konstverk eller en skönlitterär text, till form eller innehåll, bejakar skräpets hybridform kan en ny förståelse av och relation till det skapas. Skräp kan till exempel ges nya betydelser genom att placeras i oväntade sammanhang (3). Med hjälp av humor, fantasi och lek kan motsättningen mellan rent och smutsigt, fult och snyggt, sopor och värdefulla objekt upplösas (152).

\section{Absurda lekar}

På bassängkanten låg [...] en liten gädda och pustade i värmen. (Lindgren, Loranga, Loranga 87)

I Loranga, Masarin och Dartanjang och Loranga, Loranga använder sig Lindgren av det absurda för att skapa en motberättelse där gränsen mellan natur och kultur står i ständigt fokus. Överdrifter och orimligheter likt i citatet ovan skapar en antiauktoritär, karnevalistisk stämning. Till exempel vänds hierarkier mellan djur och människor upp och ner, gäddorna hoppar - som i citatet ovan - upp på land. " $\AA$, Loranga är en jättebra pappa, han bryr sej inte om nånting", konstaterar berättaren i inledningen (Lindgren, Loranga, Masarin och Dartanjang 6). Han bär morgonrock hela dagen, målar toaletten i guld i 
den första boken (84) och i den andra färgar han även TV:n "tills den glänste som en sol” (36). På Loranga, Masarin och Dartanjangs gård är allt tillåtet och möjligt.

Det absurda, karnevalistiska, groteska och nonsensartade har en given plats inom barnlitteraturen, med företrädare som Lewis Carroll och senare Lennart Hellsing och Astrid Lindgren (Druker, Modernismens bilder 159). Begreppet absurd betyder ursprungligen "orimlig, förnuftsvidrig" (SAOB) och har förknippats med litteratur kännetecknad av nonsens och bristande logik. I barnlitteraturen har det absurda mestadels en komisk och lustfylld funktion. Det gör det möjligt att omvandla och främmandegöra vardagliga föremål och platser (Druker, Modernismens bilder 161). Men det absurda och karnevalistiska har också en politisk potential. Skratt kan rubba hierarkier och kullkasta auktoriteter (Bachtin).

Den tidigare forskningen kring Lindgrens Lorangaböcker skriver in dem i en tradition av just absurdism (Lekby 1980; Boëthius; Eriksson 2002). Till exempel har släktskapet mellan Lindgrens och Samuel Becketts verklighetsgestaltning belysts av Ulf Boëthius (2014), och Janina Orlov menar att vuxenvärlden och vardagslivet görs främmande i flera av Lindgrens böcker (95). Det är emellertid i första hand AnnaKarin Kriström som uppmärksammat den politiska potentialen i Lindgrens absurdism. I De gränslösa böckerna. Om Hans Alfredson och Barbro Lindgren i 60- och 70-talens allålderslitteratur (2008) kallar hon Lindgrens estetik för en "överskridandets diskurs" (225), och hävdar att den har "en stark, med samtiden korresponderande, samhällskritisk dimension" (228). Hon beskriver hur Lindgren deltar i det omkullkastande av hierarkier som präglade tiden runt 1968 genom att lyfta fram avvikande och lågt värderade identiteter samt upphäva gränsen mellan barn-vuxen-gammal, förnuft-vansinne, människa-djur (Kriström 228).

I Lindgrens absurda gestaltningar av skräp finns emellertid ännu en koppling till samtida politiska strömningar, vilken ännu ej uppmärksammats av forskningen. Förutom att kommentera sociala normer och hierarkier bidrar Loranga, Masarin och Dartanjang och Loranga, Loranga även till den samtida miljödebatten. Barn- och vuxenkulturens estetiska teorier stod nära varandra under perioden kring 1968. 1960-talets kultur- och politiska debatter samt nya syn på lek inverkade på litteratur för alla åldrar. Leken blev politisk och vuxenkulturen mer "barnslig" (Kåreland, Inga gåbortsföremål 14). I Lorangaböckerna integreras samtida miljöfrågor indirekt i leken. Verken är fyllda av hybridformer, oväntade kombinationer av skräp och djur, elektronik och natur som synliggör den moderna, urbani- 
serade människans relation till naturen. Till de överskridanden som Kriström listar kan ett av gränsen mellan natur, kultur och avfall tilläggas. Miljön i Lorangaböckerna är klart påverkad av den genomgripande omvandling av relationen mellan natur och kultur som antropocen innebär.

Men istället för att beskriva ett nedskräpat, förorenat naturlandskap närmar sig Lindgren sophögar och granskogar från ett barnsligt perspektiv. Tilltalet är genomgående naivistiskt och såväl konservburkar som kottar inkluderas i de ständigt pågående lekar som protagonisterna ägnar sig åt. Ibland är saker uttalat på lek och huvudpersonerna leker till exempel att de är djur: "Och ideligen glömde dom bort vad dom egentligen letade efter och sprang omkring med krokiga pinnar och lekte noshörningar istället" (Lindgren, Loranga, Masarin och Dartanjang 113). Andra gånger sker övergången från människa till djur utan leken som mellanled. Till exempel får Loranga röda hund, börjar gå på alla fyra, skälla och bita folk i benen (Lindgren, Loranga, Masarin och Dartanjang 91-98).

Lindgrens metod är den motsatta mot det systematiska ordnande som beskrivs av Douglas. Istället för att skapa ordning genom att dela upp och kategorisera söker Lindgren snarare främmandegöra, förvirra och blanda samman. Det är betecknande att det bor en giraff på sophögen, den oväntade kombinationen gör att såväl djur som avfall framstår som absurda. Det absurda har i Loranga, Masarin och Dartanjang och Loranga, Loranga en politisk dimension. Gestaltningen av Lorangas lekar omöjliggör det distanserade förhållningssätt som skildringar av nedskräpning, sjukdom eller arters utdöende kan ge upphov till. I gestaltningen av sophögen, sjukdomen röda hund och den lilla gäddan lockar Lindgren istället till skratt.

\section{Lindgrens skräpestetik}

Precis som i delar av det sena 1960-talets radikala vuxenkultur är Lindgrens samhällskritik aldrig explicit utan inkorporerad i estetiken (Miller). Inledningsvis ger själva böckerna om Loranga, Masarin och Dartanjang ett skräpigt intryck. Lindgren har själv bidragit med illustrationer till såväl omslag som text. Illustrationerna på framsidan fortsätter utanför bokkanten på både Loranga, Masarin och Dartanjang och Loranga, Loranga. På den första bokens omslag finns en illustration av Loranga krypande på alla fyra. Det står "VOFF" med slarvigt handskrivna versaler framför hans mun och ena foten är kapad. På framsidan av Loranga, Loranga står han med en grön papegoja på handen. Det löst hängande morgonrocksskärpet fortsätter om 
hörnet på boken. Från papegojans näbb och ut bakom Lorangas hatt står det "GODDA LORANGA". Ordet "LORANGA" upprepas över ett dussin gånger och skär över titelns tjockare ljusblå bokstäver.

Teckningarna är naiva. Inga linjer är raka utan trevande, som att någon flera gånger med tjock svart tuschpenna letat sig fram över pappret. Vinklarna är sneda, perspektiven ofta orealistiska. Ytorna är slarvigt färglagda med samma svarta tusch, förutom på omslagen där vissa partier färglagts med rött, rosa, blått och grönt. Det ser helt enkelt skräpigt ut. Lindgren gör ingen synbar skillnad på skiss, kludd och illustration. Bilderna tycks ha växt fram organiskt, linjer som hamnar fel suddas aldrig ut utan ritas helt enkelt över. Genom att visa upp förbindelsen mellan ofärdig och färdig bild upphäver Lindgren den hierarki som vanligtvis finns emellan den "misslyckade" eller halvfärdiga och färdiga bilden.

Lindgren använder emellertid inte enbart illustrationerna för att skräpa ner och lösa upp gränser mellan natur, kultur och andra kategorier utan även språket. I böckerna om Loranga finns flera exempel på lingvistisk lek som skapar oordning, framför allt används ofta "fel" adjektiv och verb för att beskriva saker. Fåglar "suckar" och "sitter och trycker" i träden. Människor"slaskar" och pinnarna i skogen "ligger och dräller". I Loranga, Masarin och Dartanjang invaderas gården en dag av tigrar. Lindgren beskriver tigerflocken som "en hel klump med tigrar" och hur Lorangas trädgård "svämmade över av tigrar" (11). Skräp och människor dräller men knappast pinnarna i skogen. Många saker kommer i klumpar - metaller, jord, kött och trögflytande vätskor - men inte tigrar. Lindgrens ordval har en förfrämligande effekt. De grumlar alla skarpa avgränsningar mellan djur, natur och kultur.

I sin språkhantering knyter Lindgren an till den syn på barnlitteraturen som Lennart Hellsing förmedlar i Tankar om barnlitteraturen (1963). Hellsing skriver att barnlitteratur främst bör betraktas som lekmaterial. En "barnbok skall vara som en leksakslåda, där man tar upp ett och annat och leker med - vänder och vrider på ord och begrepp och historier, smakar på klanger och rytmer och bygger nya egna fantastiska luftslott - för att i nästa sekund rasa alltsammans och börja om från början igen" (43). Barnet inhämtar på så vis kunskap via lek och fantasi.

Morrison menar att parodi, intertextualitet eller ordvitsar kan läsas som en litteraturens egen återvinning. Vitsar är transgressiva och pekar mot en alternativ mening. De kan förstås som en slags avfall eller överskott, som avbryter och provocerar fram nya tankar (151-165). I en episod från första boken blir Loranga "så sugen på 
chokladpudding så han höll på att gå åt" (107). Eftersom det bara finns ett litet paket kvar inser han att det aldrig kommer gå att dela med både far och son. Han bestämmer sig för att lura Dartanjang och frågar Masarin: "'hur skulle det vara med lite choklidpöding och plispgrede?' Och så blinkade han så ögat höll på att gå i baklås" (107). Masarin förstår vinken: "Och så smet de iväg till guldtoaletten båda två och rörde ihop en härlig chokladpudding, och innan Dartanjang ens hade upptäckt att dom var försvunna, hade dom satt i sej alltihop och kom in igen mätta och belåtna" (107 f.).

Ordleken "choklidpöding och plispgrede" knyter an till såväl Lindgrens skräpestetik som Hellsings tankar om språket. I episoden ovan verkar den produktivt, hur språket används är nämligen förenat med moral (Morrison 152 f.). För att använda ett klassiskt exempel från Dante Alighieris Inferno straffas de som ägnat sig åt överdrivet smicker eller lögner i cirkel åtta genom att sänkas ner i en flod av mänskliga exkrementer eller drabbas av hemska hudsjukdomar. Med andra ord hemsöks människor som missbrukat språket av smuts, i form av avföring eller eksem.

Hos Lindgren finns ingen sådan moral. Lorangas ljugande kring "choklidpöding och plispgrede" får inga negativa konsekvenser. Det placerar förvisso lögnaren på en plats förknippad med skit men istället för att, som hos Dante, dränkas i fekalier äter far och son chokladpudding i samma färg. Lindgren språkliga lekar framkallar ett alternativt och positivt användande av toaletten. Den blir en lekplats och uppmuntrar därmed till reflektion över förbindelserna mellan mat och avfall.

\section{Smutsiga barn}

Idag är det relativt accepterat med skildringar av lek på toaletten. 2008 konstaterade Åsa Warnqvist att antalet barnbokstitlar som behandlar ämnet "bajs" ökat stadigt från 1970-talet och framåt. Ett tidigt exempel utgörs av Elmqvists miljöpolitiska Sprätten satt på toaletten (1970), där en ansvarslös kapitalist släpper ut skit i sjöar och vattendrag från sin toalett. Illustrationerna är präglade av samma skräpiga estetik som Lindgrens men i övrigt skiljer sig verken åt på flera plan. Elmqvist bilderbok är uttalat politisk, att sitta på toaletten används där som en metafor för det kapitalistiska industrisamhällets förorening av naturen.

Varken i Sprätten satt på toaletten eller i didaktiska barnböcker likt Lindgrens Max potta (1986) - där syftet är att socialisera in barnet i hur man använder potta eller toalett - relateras toaletten till något 
roligt och lekfullt. I båda fallen är smuts något som bör kontrolleras och kontrollen av det i sin tur en del av miljöpolitik och/eller socialiseringsprocess. Smuts är, för att tala med Douglas, ett tecken på att den moraliska ordningen rubbats (2). I äldre barnlitteratur finns flera exempel på verk där det rena barnet är norm. I tyska Heinrich Hoffmanns Der Struwwelpeter (1845) och svenska Ottilia Adelborgs Pelle Snygg och barnen i Snaskeby (1896) framhävs vikten av renhet. Verken har ett tydligt didaktiskt syfte, att lära barn vikten av att hålla sig rena, tvätta, skrubba och klippa sig. Ett med Lindgren samtida exempel återfinns i första avsnittet av det progressiva amerikanska barnprogrammet Sesame Street (1969-) som - trots att en gestalt, muppen Oscar the Grouch, bor i en soptunna - går ut på att lära de unga tittarna hur de ska göra när de tvättar sig. Även om programmet var revolutionerade genom sin form och moderna pedagogik är budskapet i stort detsamma som i Hoffmanns och Adelborgs böcker.

I Loranga, Masarin och Dartanjang och Loranga, Loranga gör Lindgren något annat. Lindgren är en föregångare till den barnlitteratur som först under 2000-talet gjort avföring till en del av en leken (Warnqvist). Istället för att tvätta rent låter hon saker vara smutsiga, istället för att frukta skräpet hyllar hon det. Det enda bad som förekommer är doppen i det vattenfyllda garaget och tandkrämen äter Loranga upp som godis. Huset är i oordning, far och son både äter och sover under köksbordet. I en episod försvinner deras sängar. De ger sig ut i skogen för att leta sovplats men upplösningen blir en helt annat: "Snart kom dom upp på ett berg och högst upp stod giraffen och mumsade på Lorangas säng" (Lindgren, Loranga, Masarin och Dartanjang 28). Det förekommer ingen städning i verken, varken i form av att ordna sitt hem eller kultivera naturen. Relationen mellan människa, hem, trädgård och skogen runt omkring är snarare präglad av ett ömsesidigt, slumpartat utbyte.

Ställt i relation till klassiska svenska naturskildringar är kontrasten stor. Att klassificera och kultivera naturen är till exempel centrala teman i Elsa Beskows bilderböcker. I Tomtebobarnen (1910) omvandlas skogslandskapet till ett kulturlandskap där allt tas om hand och i Puttes äfventyr i blåbärsskogen (1901) blir vilda bär till kultiverad frukt då huvudpersonen Putte krymper. Han och de andra pysslingarna skördar blåbär som vore de äpplen. Vidare beskriver Laura Fitinghoff i Barnen ifrån Frostmofjället (1907) hur de sju små värnlösa huvudpersonerna låtsas att de befinner sig i en stuga när de egentligen sover under en gran. Fördjupningarna vid stammen blir sängar och grenarna tak - att jämföra med giraffens stöld av sängen. Det är betecknande att den sophög som ligger bakom vedboden i 
Lorangaböckerna frekvent används som lekplats. En dag tror till exempel Dartanjang att sophögen på tomten är ett skepp: "Då började Dartanjang sjunga 'En sjöman älskar havets våg', och emellanåt skrek han 'babord, styrbord', så hela sophögen föll i darrning" (Lindgren, Loranga, Loranga 8).

Efterkrigstidens barn var de första barnen som faktiskt uppmuntrades till att följa Lindgrens exempel och leka med sopor. Till exempel kunde 1960-talets barn åka pulka nedför kullar konstruerade av avfall. Under slutet av 1950- och början av 60-talet placerades miljontals kubikmeter tippmassa mellan Högdalen och Hökarängen. Den täcktes med jord och förvandlades till den första Högdalstoppen. 1965 anlades en rodelbana där, 1966 en skidlift. Stockholmsbarn som inte hade råd att åka till fjällen lekte på resterna av utbyggnaden av de förorter där de också bodde, på slaggprodukterna från den urbanisering som avskilt dem från naturliga backar (Melinder och Stephenson-Möller). Därtill var vissa av de många lekplatser som byggdes under efterkrigstiden så kallade "skrammelplatser" eller "bygglekar", parker där barn själva fick bygga med gammalt bråte, skräp och brädor (Stahre).

De nya urbana och skräpbaserade lekplatserna utgick från samtida aktivitetspedagogiska idéer och var till en början dels inspirerade av modernism och funktionalism, dels av nya tankar om barns rätt $\mathrm{i}$ samhället (Östberg 97; Druker, Modernismens bilder 65 ff.). Urbaniseringen och motoriseringen av Sverige och övriga västvärlden inkräktade på barns rörelsefrihet och förändrade synen på barns lekmöjligheter. Frågan om var leken skulle ta plats var högaktuell och under perioden kring 1968 skapades flera nätverk och organisationer som på olika sätt sökte efter lösningar på problemet. 1961 bildades The International Play Association, en organisation vars syfte var att främja barns rätt till lek. Organisationens arbete resulterade bland annat i Declaration of the Child's Right to Play (1977). Inte minst den ökande biltrafiken oroade allmänheten. I häftet Tjäna på att veta om lekplatser (1968) utgivet av Kooperativa förbundets Lekråd, beskrivs till exempel hur många av barnens självvalda lekplatser i det moderna samhället blivit "farliga" (2). Skrammelplatserna var ett försök att inkludera barnen i urbaniseringen, låta dem via lek ta kontroll över utvecklingen (Stahre).

Gestaltningen av Loranga, Masarin och Dartanjangs lekar utgår från samma premisser som skrammelplatsen eller Högdalstoppen. Lindgren konstruerar sina lekrum med hjälp av vardagens bortglömda bråte, alltifrån gamla gurkor till konservburkar kommer till användning. Barn som växer upp på sophögar är på samma gång 
skrämmande verklighet som en del av motivsfären inom en traditionell miljödiskurs. De är exempel på den typ av narrativ som Hawkins menar ger upphov till en känsla av hopplöshet. Verklighetens skrammelplatser och Lorangaböckernas lekmotiv söker istället skapa en positiv relation till skräpet. Verken är en del i en samtida trend där smuts inkluderas i barns lek och bejakas istället för att tvättas bort. Med Lorangas guldtoalett och Dartanjangs skepp av sopor skapar Lindgren alternativa lekplatser i avsaknad av regler och ansvar.

\section{Trasiga leksaker}

I Loranga, Masarin och Dartanjang och Loranga, Loranga är gränsen mellan ting och levande varelse alltid flytande. Lekskildringarna innehåller ofta olika typer av överträdelser. Ett exempel återfinns i den första boken, när gården invaderats av tigrar:

\footnotetext{
Rakt ner som två spikar dök [Loranga och Masarin], ner till bilen som stod och glimmade på botten. Och därinne satt det tigrar! Säkert tretti stycken huller om buller och åt smörgåsar med prickig korv som blivit kvar efter en picknick.

Flera av tigrarna hade bleknat i vattnet och på en del hade öronen lossnat, och svansarna hängde och slängde på trekvarten. (Lindgren, Loranga, Masarin och Dartanjang 13)
}

Morrison menar att skräp har agens. Hon stödjer sig på Jane Bennetts tankar om materialitet från Vibrant Matter. A Political Ecology of Things (2010) och skriver att ett erkännande av skräpets agens kan leda till en reduktion av avfallsproduktionen. Om sopor förstås som kraftfulla agenter ökar den ekologiska medvetenheten. Antropomorfa objekt och djur motverkar en syn på natur och kultur som åtskilda (12). I citatet ovan blandas natur och kultur, skräp och leksaker. Vilda djur omvandlas till något som mest av allt liknar sopor eller trasiga gosedjur. Samtidigt är tigrarna antropomorfa, de äter smörgås. När tigrarna går från att vara djur till mänskliga till avfall underminerar de en världsbild där natur-kultur utgör ett binärt motsatspar.

Levande men slitna och bortglömda leksaker förekommer även i andra verk av Lindgren såsom trilogin Vems lilla mössa flyger (1987), Korken flyger (1990) och VLMF. Vad lever man för (2006). Där kan man komma till "Barnhans land" genom ett hål i en häck. Landet liknar en soptipp och är befolkat av gamla trasiga gosedjur, vilka på många sätt liknar tigrarna i citatet ovan. Orlov kallar platsen för ett "barndomsmuseum där museiföremålen lever" (94). Genom att skildra sönderfallande leksaker låter Lindgren ålderdomen och döden in- 
korporeras i barndomens rum (94). Böckerna bygger vidare på en tradition av leksaksskildringar med A. A. Milnes Winnie-the-Pooh (1926) som typexempel.

De antropomorfa trasiga tigrarna är inte de enda leksakerna i de två böckerna om Loranga. Huvudpersonerna leker med det mesta. Ett centralt tema utgår från lek med mat, den tidigare nämnda ordleken "choklidpöding och plispgrede" är ett exempel på det. I två avsnitt av Loranga, Masarin och Dartanjang spelar far och son ishockey på gräsmattan med sopborstar som klubbor och en grönsak som puck:

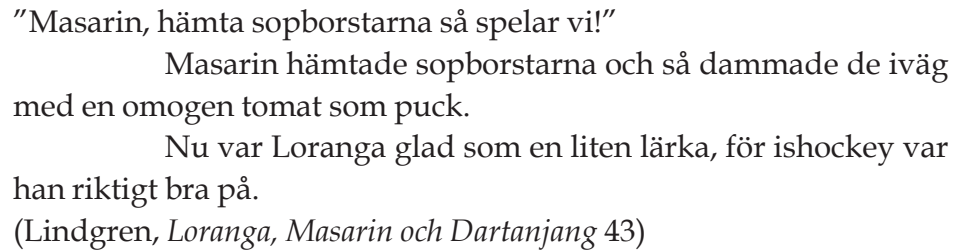

Här använder de en grön tomat och tidigare i samma verk har de tagit en "övermogen apelsin" (24). När de tröttnat på spelet äter Masarin upp pucken som då åter är tomat, om än omogen. Scenen knyter an till antistädtemat - sopborstarna används till lek istället för rengöring - men framför allt aktualiserar den frågor om konsumtion och renhållning, vad som ska brukas, slängas, ätas eller rengöras.

I en viss typ av miljöfrågeinriktad barnlitteratur från 1970-talet och framåt läggs ansvaret för att städa upp i naturen på barnprotagonister. Där kan barnen göra det som vuxenvärlden förstört fint igen. Elina Druker tecknar, i artikeln "Från dystopier till eco chic. Miljökritiska bilderböcker från 1970-talet och i dag" (2010), den miljökritiska barnbokens historia. Hon beskriver hur barnet ofta skildras som ett med naturen medan vuxenvärlden relateras till industrier, miljöföroreningar och dystopiska urbana miljöer i barnböcker från finska Kaarina Helakisas Elli-velli-karamelli (1973) till senare verk som Emma Brownjohns Så kan jag ta hand om jorden (2007) och Lauren Childs Hjälp vår jord! (2008). På omslaget till Jörn Spolanders Cykla, panta och rädda en isbjörn (2008) står det: "Man behöver inte vänta till man är vuxen, har körkort och rösträtt för att rädda världen kanske är det till och med bättre att vara barn?!" I dylika uppmaningar läggs mycket ansvar på barnen själva. Druker menar att John Dryzeks term "green romanticism" utgör en passande beskrivning av hur barnens relation till naturen gestaltas i den typen av litteratur. Barnet skrivs fram som en etisk agent med stort ansvar för natur och miljö (Druker, "Från dystopier till eco chic" 14). 
Även när Lindgren inkluderar trasiga leksaker och sopor i leken skrivs en kritik mot konsumtionssamhället fram som svarar mot samtidens syn på miljö och ansvar. Loranga och Masarins lekar väcker frågor om sakers funktion och värde: När ska mat slängas? När är leksaker för gamla att lekas med? Detta sker dock utan att barnet behöver bära ansvaret för framtiden på sina axlar.

Det är dock inte enbart ett erkännande av skräpets agens som kan leda till ökad medvetenhet om ekologi, en omvärdering av föremåls värde kan också bidra till att reducera avfallsproduktionen (Morrison 12). Hos flera av Barbro Lindgrens verk är skräpet påtagligt inkluderat i vardagen. Såväl Mattias i trilogin Mattias' sommar (1965), Mera om Mattias (1966) och Hej, hej Mattias (1967), som huvudpersonen i Lilla Sparvel (1976) och Stora Sparvel (1977) letar efter saker i dikena utmed vägen. Barnen hittar skräp som de tar för skatter. I Lilla Sparvel skrattar Sparvels mormor och tycker att barnbarnets fynd är skrot. I en lång inre monolog ondgör sig Sparvel över sin mormors inställning: "Nästan allt som Sparveln tyckte var fint var bara skräp! [...] Men riktigt fula saker är alltid fina, konstigt nog. Det finns tavlor, fullsmetade med färg och fula streck, som är värda miljoner!" (Lindgren, Lilla Sparvel 97). Såväl smak som konsumtionsvanor ifrågasätts av det upprörda barnet. I böckerna om Loranga finns ingen vuxen röst som säger att skräpet är just skräp. Skräpestetiken är med andra ord mer genomgående än i de övriga verken.

\section{Slutord: Återförtrollning}

Skräp är politiskt. Det kan fokusera orättvisor, värderingar och normer - det avfall som är osynligt för vissa är ett sätt att överleva för andra. Det kan våldföra sig på sinnena men även överraska, reklameras och genomgå metamorfoser.

I barnlitteratur och kultur har det haft flera funktioner. Under åren kring 1968 användes det för att kommentera och kritisera konsumtionssamhället, ifrågasätta estetiska normer och överbygga gränser mellan binära motsatspar som natur-kultur och kultur-avfall. Sopor, avfall och smuts har dels inkluderats i en traditionell miljödiskurs, dels ingått i motberättelser.

Loranga, Masarin och Dartanjang och Loranga, Loranga kan läsas som exempel på motberättelser. Lindgrens böcker kombinerar det absurda och eskapistiska med frågor om miljöförstörelse. Likt skrammelplatserna - och till skillnad från uttalat miljökritiska verk likt Elmqvist Sprätten satt på toaletten - uppmuntrar böckerna till en produktiv och lekfull relation till sopor och skräp. Lindgrens verk 
är en del i en barnlitterär trend där skräp ges nya betydelser och gestaltas positivt. Sopor inkluderas i allt från Jan Lööfs bilderbok Skrot-Nisse (1976) till Christina Lagersons och Ove Magnussons barnprogram Från A till Ö (1974-75).

Återvinningsmotiv och lek med sopor finns självklart också i tidigare barnlitteratur. Till exempel bär gestaltningen av det oordnade hemmet, de karnevalistiska lekarna och sakletandet i Astrid Lindgrens Pippi Långstrump (1945) flera likheter med de i Lorangaböckerna. I Mio, min Mio (1954) hittar Bosse en gammal tomflaska som visar sig innehålla en ande som kan föra honom bort från hans ensamma urbana vardag till "Landet i fjärran". Där är skräpet dock inte en del av den övergripande estetiken utan har en transgressiv funktion och är nära förbundet med det fantastiska. Tillsammans skapar de nämnda verken ett alternativ till kampanjer som "Håll Sverige Rent", där syftet är att återställa en tänkt ordning.

Genom att läsa Lorangaböckerna utifrån ett ekokritiskt perspektiv kan bilden av den miljöpolitiska barnboken nyanseras. Av artikeln framgår att Lindgren bryter det apatiska tillstånd som Hawkins menar är en konsekvens av ensidigt negativa gestaltningar av miljöproblem. Istället bidrar hon till att etablera en mer nyanserad relation mellan barn, skräp och miljö. Loranga, Masarin och Dartanjang och Loranga, Loranga skapar ett alternativ genom att förändra förståelsen av människans relation till naturen och väcka intresse för soporna. När vardagen främmandegörs och blandas med nonsens och absurdism öppnas ett rum för estetisk och politisk reflektion.

Därtill bryter verken med en barnlitterär tradition där barnet förknippas med natur, oskuld och renhet. I Lorangaböckerna är naturen inget passivt offer för mänsklig exploatering och förorening, den har ingen ursprunglig renhet eller helighet som kan gå förlorad. Lindgren överbygger istället dualismen mellan mänsklig kultur och ickemänsklig natur och återförtrollar på så sätt naturen.

Biografisk information: Lydia Wistisen är postdoktor i litteraturvetenskap vid Stockholms universitet. Hon disputerade 2017 med avhandlingen Gångtunneln. Urbana erfarenheter i svensk ungdomslitteratur 1890-2010. Hon ingår i redaktionsrådet för Barnelitterært Forskningstidsskrift samt recenserar barn- och ungdomsböcker $i$ Dagens Nyheter. 


\section{Litteratur}

"Absurd". Svenska Akademiens Ordbok, 30 aug 2018, https://www. saob.se/artikel/?seek=absurd.

Adelborg, Ottilia. Pelle Snygg och barnen i Snaskeby. Stockholm, Bonnier, 1896.

Andersson, Christopher Todd. "Sacred Waste. Ecology, Spirit, and the American Garbage Poem". Interdisciplinary Studies in Literature and Environment, nr. 1, 2010, s. 35-60.

Bachtin, Michail. Rabelais och skrattets historia. François Rabelais' verk och den folkliga kulturen under medeltiden och renässansen. Översatt av Lars Fyhr, Gråbo, Anthropos, 2007.

Bauman, Zygmunt. Wasted Lives. Modernity and its Outcasts. Cambridge, Polity, 2004.

Bennett, Jane. Vibrant Matter. A Political Ecology of Things. Durham, Duke University Press, 2010.

Beskow, Elsa. Puttes äfventyr i blåbärsskogen. Stockholm, 1901.

---. Tomtebobarnen. Göteborg, Åhlén \& Åkerlund, 1910.

Boëthius, Ulf. "Barbro Lindgren barnens egen Beckett". Svenska Dagbladet, 30 maj 2014.

Boström, Magnus. Den organiserade miljörörelsen. Fallstudier av Svenska Naturskyddsföreningen, Världsnaturfonden WWF, Miljöförbundet Jordens Vänner, Greenpeace och Det Naturliga Steget. Stockholm, Stockholms centrum för forskning om offentlig sektor, Stockholms universitet, 1999.

Brownjohn, Emma. Så kan jag ta hand om jorden. Översatt av Cecilia Flink, Stockholm, Globe, 2007.

Child, Lauren. Hjälp vår jord! Översatt av Lotta Olsson, Stockholm, Rabén \& Sjögren, 2008.

Dini, Rachele. Consumerism, Waste, and Re-Use in Twentieth-Century Fiction. Legacies of the Avant-Garde. New York, Palgrave Macmillan, 2016.

Douglas, Mary. Purity and Danger. An Analysis of Concepts of Pollution and Taboo. London, Routledge \& K Paul, 1966.

Druker, Elina. "Från dystopier till eco chic. Miljökritiska bilderböcker från 1970-talet och i dag”. Horisont, nr. 1, 2010, s. 12-17. 
---. Modernismens bilder. Den moderna bilderboken i Norden. Diss., Stockholms universitet, 2008. Stockholm, Makadam, 2008.

Elmqvist, Annika. Sprätten satt på toaletten. Stockholm, Rabén \& Sjögren, 1970.

“Episode 1", Sesame Street. NET, United States, 10 nov. 1969.

Eriksson, Jerker. Trevliga begravningar. Nonsens, komik och allvar i Barbro Lindgrens Loranga- och Barnhansböcker. Uppsala, Litteraturvetenskapliga institutionen, 2002.

Fitinghoff, Laura. Barnen ifrån Frostmofjället. Stockholm, Ljus, 1907.

Gee, Sophie. Making Waste. Leftovers and the Eighteenth-Century Imagination. Princeton, Princeton University Press, 2009.

Gäst i naturen. Stockholm, Svenska Naturskyddsföreningen, 1963.

Haraldsson, Désirée. Skydda vår natur! Svenska Naturskyddsföreningens framväxt och tidiga utveckling. Diss., Lund, Lunds universitet, 1987.

Hawkins, Gay. The Ethics of Waste. How We Relate to Rubbish. Lanham, Rowman \& Littlefield, 2005.

Helakisa, Kaarina. Elli-velli-karamelli. Espoo, Weilin \& Göös, 1973.

Hellsing, Lennart. Tankar om barnlitteraturen. Stockholm, Rabén \& Sjögren, 1963.

Hoffmann, Heinrich. Der Struwwelpeter oder Lustige Geschichten und drollige Bilder für Kinder von 3 bis 6 Jahren. Frankfurt a. M., Literarischer Verein, 1845.

Kriström, AnnaKarin. De gränslösa böckerna. Om Hans Alfredson och Barbro Lindgren $i$ 60- och 70-talens allålderslitteratur. Diss., Uppsala universitet, 2006. Stockholm, Eriksson \& Lindgren, 2008.

Kåreland, Lena. Barnboken i samhället. 2 uppl., Lund, Studentlitteratur, 2013.

---. Inga gåbortsföremål. Lekfull litteratur och vidgad kulturdebatt i 1960och 70-talens Sverige. Göteborg, Makadam, 2009.

Lagerlöf, Selma. Nils Holgerssons underbara resa genom Sverige. Stockholm, Bonnier, 1906.

Lagerson, Christina och Ove Magnusson. Från A till Ö.SVT, 1974-75.

Land att vårda. Stockholm, Svenska Naturskyddsföreningen, 1965. 
Latour, Bruno. Nous n'avons jamais été modernes. Essai d'anthropologie symétrique. Paris, La Découverte, 1991.

Lekby, Astrid. Absurdism i Barbro Lindgrens Lorangaböcker. Med anknytning till Kornej Tjukovskijs arbete Från två till fem år. Om barns språk, dikt och fantasi. Uppsala, Litteraturvetenskapliga institutionen, 1981.

Lindgren, Astrid. Pippi Långstrump. Stockholm, Rabén \& Sjögren, 1945.

---. Mio, min Mio. Stockholm, Rabén \& Sjögren, 1954.

Lindgren, Barbro. Hej, hej Mattias. Stockholm, Rabén \& Sjögren, 1967.

---. Korken flyger. Stockholm, Rabén \& Sjögren, 1990.

---. Lilla Sparvel. Stockholm, Rabén \& Sjögren, 1976.

---. Loranga, Loranga. Stockholm, Rabén \& Sjögren, 1970.

---. Loranga, Masarin och Dartanjang. Stockholm, Rabén \& Sjögren, 1969.

---. Mattias' sommar. Stockholm, Rabén \& Sjögren, 1965.

--- Max potta. Stockholm, Rabén \& Sjögren, 1986.

---. Mera om Mattias. Stockholm, Rabén \& Sjögren, 1966.

---. Stora Sparvel. Stockholm, Rabén \& Sjögren, 1977.

---. Vems lilla mössa flyger. Stockholm, Rabén \& Sjögren, 1987.

---. VLMF. Vad lever man för. Stockholm, Rabén \& Sjögren, 2006.

Lööf, Jan. Skrot-Nisse. Stockholm, Carlsen, 1976.

Melinder, Karin och Henrik Stephenson-Möller. Jag tycker det är kul att det finns fjäll $i$ Stockholm. En studie av Högdalstoppen. Huddinge, Bergsstugan konsult, 2013.

Miller, Timothy. The Hippies and American Values. Knoxville, University of Tennessee Press, 2012.

Milne, A. A. Winnie-the-Pooh. London, Methuen, 1926.

Morrison, Susan Signe. The Literature of Waste. Material Ecopoetics and Ethical Matter. New York, Palgrave Macmillan, 2015.

Morton, Timothy. The Ecological Thought. Cambridge, Harvard University Press, 2010.

Mählqvist, Stefan. "Barbro Lindgren". Författare $\mathcal{E}$ illustratörer för barn och ungdom. Porträtt på svenska och utländska nutida författare och illustratörer. 5, Le-Ma. Lund, Bibliotekstjänst, 1999, s. 131-150. 
Orlov, Janina. "Vägen till Barnhans land eller Ormen i paradiset. Barndomen som rum i Barbro Lindgrens författarskap". Barnlitteraturanalyser, redaktörer Maria Andersson och Elina Druker, Lund, Studentlitteratur, 2008, s. 83-96.

Paulsson, Eva S. Tjäna på att veta om lekplatser. Stockholm, Kooperativa förbudet, 1968.

Rikskampanjen Hål Sverige rent 1970-1974. Stockholm, Rikskommittén Håll Sverige rent, 1974.

Spang Olsen, Ib. Røgen. Köpenhamn, Gyldendal, 1970.

Spolander, Jörn. Cykla, panta och rädda en isbjörn. Stockholm, Alfabeta, 2008.

Stahre, Ulf. Den alternativa staden. Stockholms stadsomvandling och byalagsrörelsen. Diss., Göteburgs universitet, 1999. Stockholm, Stockholmia, 1999.

Warnqvist, Åsa. "Det är mycket skit i barnböckerna". Svenska Dagbladet, 22 september 2008.

Östberg, Kjell. 1968 när allting var i rörelse. Sextiotalsradikaliseringen och de sociala rörelserna. Stockholm, Prisma, 2002. 